AGRICULTURE AND BIOLOGY JOURNAL OF NORTH AMERICA

ISSN Print: 2151-7517, ISSN Online: 2151-7525, doi:10.5251/abjna.2013.4.3.316.319

(C) 2013, ScienceHuß, http://www.scihub.org/ABJNA

\title{
Bionomics of Helminth Parasites in Goats of Subtropical Jammu Area of J\&K, India
}

\author{
Muzaffar Rasool Mir ${ }^{\star}$, M. Z. Chishti, S. A. Dar, Majidah Rashid \\ Department of Zoology, the University of Kashmir, Srinagar-190006 \\ ${ }^{*}$ Correspondence authors e-mail: muzaffarmir2@gmail.com
}

\begin{abstract}
A survey was carried out on the prevalence of gastrointestinal (GI) helminthes in 284 goats in different areas of subtropical Jammu region of Jammu and Kashmir State. Necroscopic examination revealed $72.88 \%$ of infection. The gastrointestinal helminthes isolated were Haemonchus contortus (28.87\%), Trichuris ovis (14.43\%), Paramphistomum cervi $(6.69 \%)$, Fasciola hepatica (5.28\%), and Chabertia ovine (4.57\%,) Dicrocillium dendriticum (3.87\%), Dictyocaulus filarae (3.52\%), Stilesia globipunctata (3.52\%) and Monezia expansa (2.11\%) The seasonal distribution of infection indicated a higher percentage of infection in summer and winter followed by spring and autumn.
\end{abstract}

Key words: Bionomics, Helminthes, Gastrointestinal, Jammu.

\section{INTRODUCTION}

Gastrointestinal parasitism is one of the major health problems severely limiting the productivity of dairy animals in the Himalayan and other regions of India (Jithendran and Bhat, 1999). Clinical and subclinical infection with internal parasites reduces the productivity of small ruminants (Gall, 1981) and gastrointestinal helminth parasites are responsible for significant production losses in grazing ruminants throughout the world (Sykes, 1994). Gastrointestinal parasitism is a major cause of low productivity, unthriftness and occasional death in farm animals (Sood, 1981). Studies on the incidence of gastrointestinal parasites in small ruminants have been reported from different states of India (Bali, 1973; Mishra et al., 1974; Katoch et al., 1998; Hirani et al., 1999; Maske et al., 1990; Deka et al., 1995 and Talukdar, 1996). In Jammu and Kashmir, the incidence has been reported by many workers viz., Dhar et al.,(1979), Sharma et al.,(1989), Pandit et al.,(1989), Gupta et al.,(1990), Makhdoomi et al.,(1995), Khajuria et al.,(2003), Yadav et al.,(2006), Fayaz et al.,(2007), Kuchay et al. (2011).

The present investigation records the outbreak of different kinds of helminth parasites in goats with the associated epidemiological information in subtropical area of Jammu.

\section{MATERIAL AND METHODS}

A total of 284 goats from different places of subtropical Jammu were examined and screened between November 2007 to October 2008 for various types of helminth parasites. The gut of freshly slaughtered animal at local slaughter house were collected and scanned. The main sites observed for parasitic infection were digestive tract including stomach, small and large intestine. The other organs collected for the presence of helminth includes liver and lungs. The study revealed a complete spectrum of helminth parasites whose identification was confirmed from morphological features (Solusby 1982).

\section{RESULTS AND DISCUSSION}

Out of 284 goats screened for helminthic infestation 207 were found positive for one or more than one types of infections revealing a total percentage of $72.88 \%$.

The gastrointestinal helminthes isolated during the present study were Haemonchus contortus (28.87\%), Trichuris ovis (14.43\%), Paramphistomum cervi (6.69\%), Fasciola hepatica (5.28\%), Chabertia ovina (4.57\%), Dicrocillium dendriticum (3.87\%), Dictyocaulus filarae (3.52\%), Stilesia globipunctata $(3.52 \%)$ and Monezia expansa $(2.11 \%)$ as shown in table $1 a$ and figure $1 \mathrm{~b}$. The data regarding the percentage of infection according to seasons is presented in table $\mathbf{2 a}$ and figure $\mathbf{2} \mathbf{b}$. The maximum prevalence of $88.13 \%$ was recorded in summer followed by $78.3 \%$ in winter, $68.75 \%$ in spring and $58.97 \%$ in autumn. The higher incidence of parasitism and isolation of wide spectrum of parasites is in general agreement with the findings of other workers from the different study areas of Jammu and Kashmir (Dhar et al., 1979; Pandit et al., 1989; 
Ahmad et al., 1990; Khajuria et al., 2003; Yadav et al., 2006; Fayaz et al., 2007 and Kuchay et al., 2011). Our findings are also in agreement with the findings of various authors from other areas of India (Dhanalakshmi et al., 2001; Swarankar et al., 1996; Hirani et al., 1999; Jithendren et al., 1998; NATP report, 2004 and Pal et al., 2004).

The seasonal occurrence of parasitic infection in goats depicts higher infection of helminthes in summer followed by winter, spring and lowest in autumn. Similar types of findings as reported by Makhdoomi et al., 1995; Khajuria et al., 2003; Nasreen et al., 2005 and Yadav et al., 2006 from the same study areas. Our findings are also in agreement with the studies of other people (Solusby, 1982; Singh et al., 1997; Colwell, 2002 and Lateef et al., 2005) from various parts of the world. The reason for the higher prevalence during summer could be due to favorable ecological and environmental conditions of the study area. The high temperature and humidity during the summer provides a conducive atmosphere for luxurious growth of infective larvae on pasture and increased infestation among goats. The seasonal dynamics of nematode infection are the consequence of complex interrelationships between the goat, their husbandry and the prevailing climate. Larval numbers on pastures tend to build up through spring and summer, reaching a peak in the autumn. Remnants of this autumn peak survive over winter, and are a major source of infection of new animals the following spring.

Table. 1a: Species wise prevalence of gastrointestinal helminthes in goats.

\begin{tabular}{|l|l|l|l|l|}
\hline S. No. & Species & $\begin{array}{l}\text { No. of animals } \\
\text { examined }\end{array}$ & Total positive & $\begin{array}{l}\text { Infection } \\
\text { percentage }\end{array}$ \\
\hline 1 & Paramphistomum cervi & 284 & 19 & $6.69 \%$ \\
\hline 2 & Dicrocillium dendriticum & 284 & 11 & $3.87 \%$ \\
\hline 3 & Fasciola hepatica & 284 & 15 & $5.28 \%$ \\
\hline 4 & Trichuris ovis & 284 & 41 & $14.43 \%$ \\
\hline 5 & Dictyocaulus filarae & 284 & 10 & $3.52 \%$ \\
\hline 6 & Haemonchus contortus & 284 & 82 & $28.87 \%$ \\
\hline 7 & Chabertia ovine & 284 & 13 & $4.57 \%$ \\
\hline 8 & Monezia expansa & 284 & 6 & $2.11 \%$ \\
\hline 9 & Stilesia globipunctata & 284 & 10 & $3.52 \%$ \\
\hline & Total & 284 & 207 & $72.88 \%$ \\
\hline
\end{tabular}

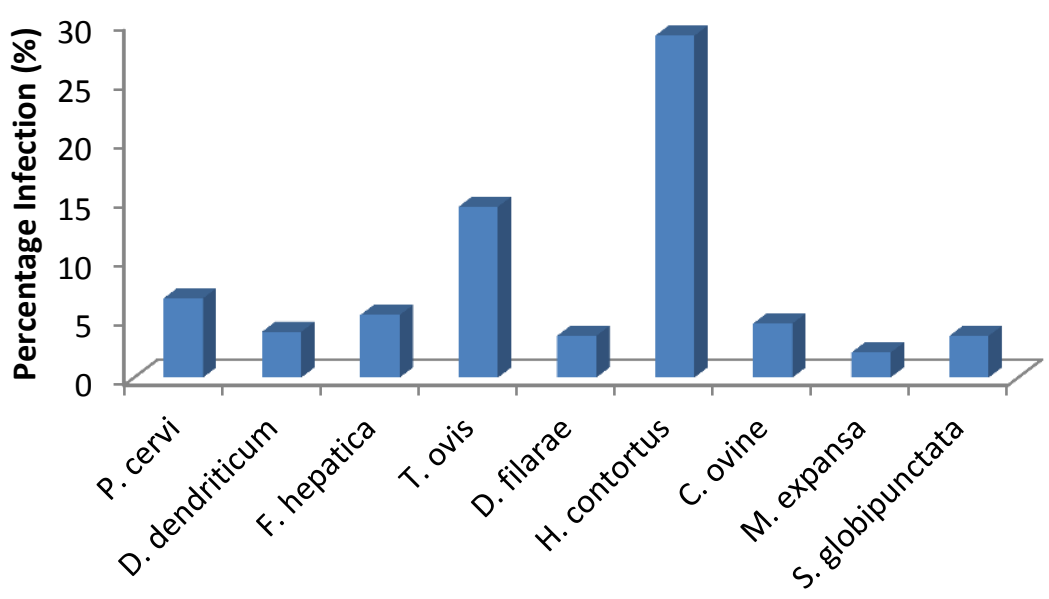

Fig. 1b: Species wise prevalence of gastrointestinal helminthes in goats. 
Table 2a. Seasonal prevalence of gastrointestinal helminth infection in goats.

\begin{tabular}{|c|c|c|c|c|}
\hline S. No. & Season & $\begin{array}{c}\text { No. of animals } \\
\text { examined }\end{array}$ & $\begin{array}{c}\text { No. of animals } \\
\text { positive }\end{array}$ & $\begin{array}{c}\text { Percentage of } \\
\text { infection }\end{array}$ \\
\hline 1 & Summer & 59 & 52 & $88.13 \%$ \\
2 & Autumn & 78 & 46 & $58.97 \%$ \\
3 & Winter & 83 & 65 & $78.3 \%$ \\
4 & Spring & 64 & 44 & $68.75 \%$ \\
\hline Total & & 284 & 207 & $72.88 \%$ \\
\hline
\end{tabular}

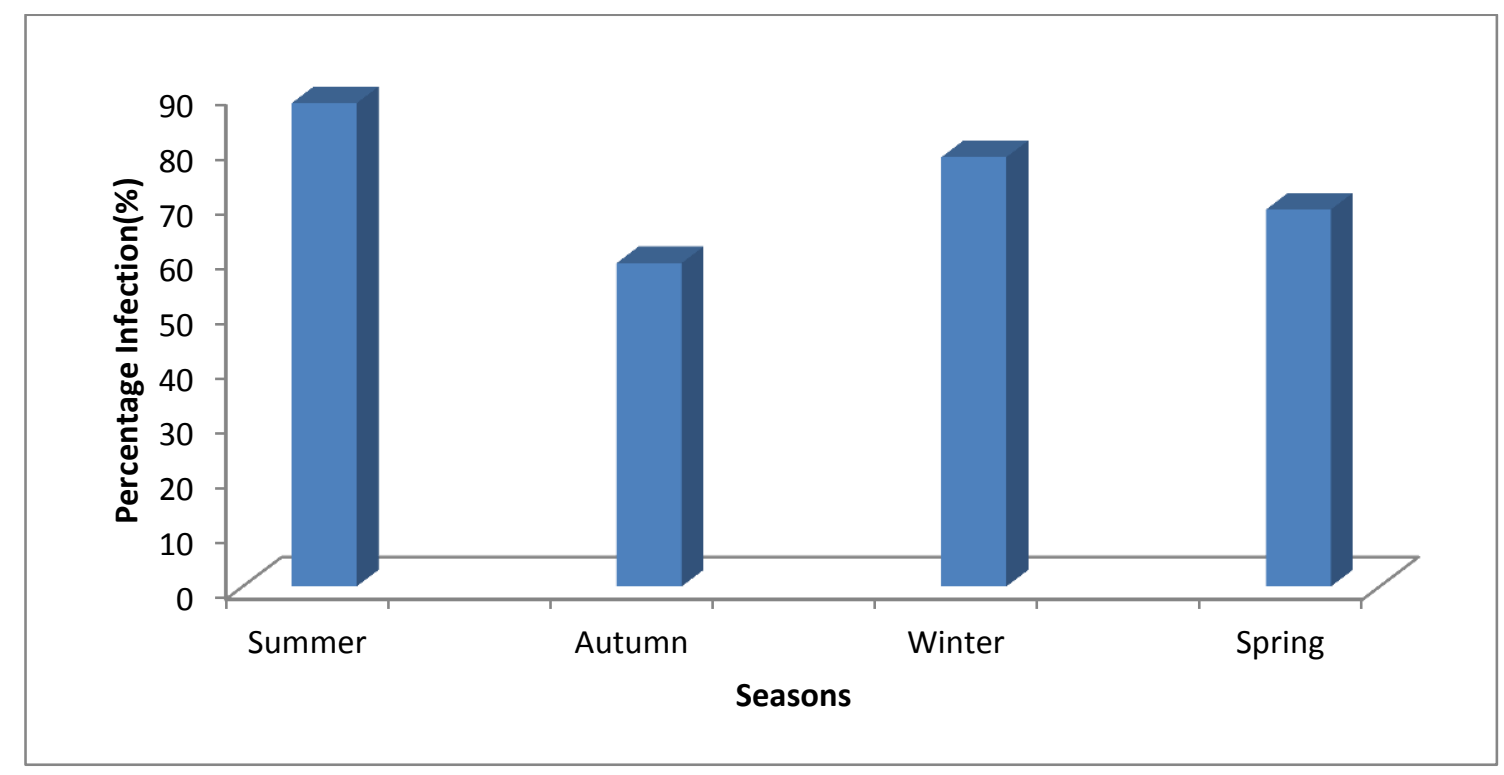

Fig 2 b. Seasonal prevalence of gastrointestinal helminth infection in goats.

\section{ACKNOWLEDGEMENT}

The authors are thankful to the staff of district animal husbandry and sheep husbandry departments of Jammu and P G Department of Zoology the University of Kashmir for providing the laboratory facilities.

\section{REFERENCES}

Ahmad, F.; Tariq, K. A.; Chishti, M. Z. 2007. Epidemiological studies on haemonchosis of sheep in Kashmir valley. Oriental Sci. 12: 43-47.

Ahmad, M. A., Mir, A.S., Pandit,B.A. and Kirmani, M. A., 1990. Albendazole in the treatment of gastrointestinal nematodes in sheep. J. Vet. Parasitol., 4: 77-78.

Bali, H. S., 1973. Incidence of helminth parsites in sheep in Bihar. J. Anim. Hlth. Prod., 1: 35-39.

Colwell, D.D.; Goater, C.P. and Jacobson, K. M. 2002. Prevalence and intensity of gastrointestinal nematodes in slaughter lambs from central Alberta. Can. Vet. J., 43(10): 775-777.
Dhanalakshmi, H., Jaganath, M. S. and Placid E. D' Souza, 2001. Gastrointestinal parasitic infections in sheep at different farms of Karnataka, J. Vet. Parasitol., 133135.

Dhar, D. N. and Sharma, R. L., 1979. A note on the prevalence of lung worm infection in sheep and goats in Tehsil kargil of district Ladakh(Jammu and akshmir). Indain J. Anim. Sci., 49: 585-588.

Gall, C., 1981. Goat production. Academic Press, London.

Gupta, S. C., Bakhshi, S. B., Kumar, S. and Singh, J., 1990. Efficiency of ivermectin against naturaly acquaired nematode infections of sheep. Indian Vet. J., 67: 673-674,

Hirani, N.D., Katariya, M.A., Patel Abdullah, Hasnani, J.J., kathisia, L.G. and Patel, P.V., 1999. Prevalence of gastrointestinal parasitic infections in cattle and buffaloes in Kheda district of Gujarat. J. Vet. Parasitol., 13: 117-119.

Jithendran, K. P. and Bhat, T. K., 1999. Epidemiology of parasites in dairy animals in the North-West Humid 
Himalayan region of India with particular reference to gastrointestinal nematodes. Trop. Anim. Hith. Prod., 31: 205-214.

Jithendran, K.P., 1998. Epidemiology of gastrointestinal nematodes in migratory sheep and goats in NorthWest Humid Himalayan Region. Indain J. Anim. Sci., 68: 894-896.

Katoch, R., Mittra, S., Agnihotri, R. K. and Sharma, A. K., 1998. Winter stronylosis in sheep and goats at high altitude. A sporadic occurrence. Indain vet. J., 75: 363.

Khajuria, J. K.; Kapoor, P. R. 2003. Prevalence of parasites in sheep and goats at Kathua- Jammu. Journal of Veterinary Parasitology, 17(2): 121-126.

Kuchay, J. A.; Chishti, M. Z.; Zaki, M. Manal; Javaid Ahmad, 2011. Prevalence of nematode parasites in sheep of Ladakh-India. Journal of Agricultural Extension and Rural Development, 3 (13): 229-231.

Lateef, M. Iqbal, Z., Jabbar, A. Khan, M. N. Akhtar, M. S., 2005. Epidemiology of trichostrongylid nematode infections in sheep under traditional husbandry system in Pakistan. International Journal of Agriculture and Biology. 7: 596-600.

Makhdoomi, D. M., Nasreen Shagufta, Banday, S. D., Moulvi, B. A., 1995. Incidence of different ovine gastrointestinal parasites in Kashmir. Indian Veterinary Journal, 72: 898-900.

Nasreen, S.; Jeelani, S. G. and Munir, H. 2005. Incidence of gastrointestinal nematodes in sheep in Kashmir valley. J. of Vet. Parasitology, 19(1): 27-29.

NATP Report, 2004. Annual progress report of National Agricultural Technological Project (Mission Mode) on diagnosis of parasitic diseases of domestic animals, ICAR, New Delhi, India.
Pal Papri and Bandyopadhyay, S., 2004. Prevalence of gastrointestinal nematodosis in goats in Sikkim. Journal of veterinary parasitology., 18(2): 127-130.

Pandit, B.A., Mir, A.S., Nasreen, S., Khan, A.A., 1989. The epidemiology of ovine fasciolosis in jammu and Kashmir state. J. Vet. Parasitol., 3: 13-15.

Sharma, R. L., Dhar, D. N. and Raina, O. K., 1989. Studies on the prevalence and laboratory transmission of fasciolasis in animals in the Kashmir valley. Br. Vet. J., 145-157.

Singh, D.; Swarnkar, C. P.; Kahn, F. A.; Srivastava, C.P.; Bhagwan, P.S.K. 1997. Epidemiology of Ovine gastrointestinal nematodes at an organized farm in Rajasthan, India. Small Ruminant Research. 26(1/2): 31-37.

Skyes, A. R., 1994. Parasitism and production in farm animals. Anim. Prod., 59:155-172.

Sood, M. L., 1981. Haemonchus in india. Parasitology, 83: 639-650.

Soulsby, E. J. L. 1982. Helminths, Arthopords and protozoa of Domesticated animals, $7^{\text {th }}$ Ed. The English Book society and bailliere Tindall, London.

Swarankar, C. P., Singh, D., Srivastav, C. P., Bhagwan, P. S. K. and Dimiri, U., 1996. A retrospective study on ovine gastrointestinal helminthiosis under semi-arid conditions. J. Vet. Parasitol., 10: 15-21.

Yadav, A.; Khajuria, J. K.; Raina, A. K. 2006. Seasonal prevalence of gastrointestinal parasites in sheep and goats of Jammu. Journal of Veterinary Parasitology, 20(1): 65-68. 